\author{
Miroshnichenko Svetlana \\ Ph.D. in History of Art, Professor, \\ Professor of the Theory of Music \\ and Composition Department \\ Odessa National A. V. Nezhdanova Music Academy \\ ORCID 0000-0002-3961-0661 \\ svet12024@gmail.com
}

\title{
PECULIARITIES OF A TONAL PLAN OF THE POLYPHONIC CYCLE "36 FUGUES FOR PIANO" BY ANTONIN REICHA
}

The purpose of the article is to consider and analyze interaction of tonalities in three volumes of the piano polyphonic cycle of Antonin-Josef Reicha (1770-1836) "36 fugues for piano" and to make a conclusion about peculiarity of a unique tonal plan as well as to show the prospectivity of projection of this cycle for the works of the subsequent composers of this genre. The methodology of the article - methods of historical and cultural, theoretical and genre-style analysis have been applied, which made it possible to highlight peculiarity and uniqueness of atonal polyphonic thinking, creative individuality of Antonin-Josef Reicha in the context of the further research of the development of polyphonic works of the composers of the XX century. The scientific novelty lies in the fact that for the first time a polyphonic creative system of Reicha is revealed. It is filled with fundamental originality originating from a composer's classical and romantic style. By an analysis of the polyphonic piano cycle "36 fugues," we can state that Reicha anticipates polyphonic thinking of many subsequent composers. A creative style of the composer hasn't been studied in contemporary musicology. For the first time, a tonal plan of a three-volume piano polyphonic cycle of the Classicism epoch of "36 fugues for piano" (1805) by A. Reicha is analyzed. Moreover, his personality in domestic musicology was revealed only in our articles. Conclusions. Tonal thinking in the polyphonic cycle of Antonin-Josef Reicha looks far ahead. A tonal plan of a piano polyphonic cycle "36 fugues for piano" by A.Reicha is unique, and there is no such precedent. He as if combines past of the Baroque and contemporary future. The polyphonic cycle of Reicha turned out an intermediate link between polyphonists of the Baroque epoch and subsequent centuries because he absorbed the basics of the Baroque, Classicism, Romanticism and anticipated the future of the musical language of the XX century to a great extent. A very complex correlation of the tonal supports of the first degree of kinship and their interaction is formed. The article offers perspectives on the influence of this polyphonic piano cycle on similar genres of Ukrainian composers.

Key words: the polyphonic cycle of A. Reicha; tonal plan; the first degree of relationship; the interaction of tonalities; tonal supports; J. S. Bach; D. Shostakovich; R. Shchedrin; V. Zaderatsky.

Мірошниченко Світлана Володимирівна, кандидат мистецтвознавства, професор, професор кафредри теорії музики і композиції Одеської національної музичної академії імені А.В. Нежданової

Особливості тонального плану поліфонічного циклу «36 фуг для фортепіано» Антоніна Рейха

Мета статті - розглянути й проаналізувати взаємодію тональностей у трьох томах фортепіанного поліфонічного циклу Антоніна-Джозефра Рейха (1770-1836) «36 фуг для фортепіано» (1805) та зробити висновки про своєрідність його унікального тонального плану, а також показати перспективність проекції вказаного циклу для творів інших композиторів саме цього жанру. Методологія статті. Застосовано методи історико-культурологічного, теоретичного та жанрово-стильового аналізу, що дозволило виявити особливості й неповторність тонального поліфонічного мислення, творчу індивидуальність Антоніна-Джозефа Рейха в контексті подальшого дослідження розвитку поліфонічної творчості композиторів XX століття. Наукова новизна полягає в тому, що вперше розкривається поліфонічна творча система Рейха, наповнена принциповою новизною, що випливає 3 класичного й романтичного стилю композитора. Виходячи з аналізу фортепіанного поліфонічного циклу «36 фруг», можна ствержувати, що Рейх передбачає поліфонічне мислення багатьох послідовників-композиторів. Творчий стиль композитора не досліджений у сучасному музикознавстві. Вперше аналізуєтся тональний план тритомного фортепіанного поліфонічного циклу епохи класицизму - «36 фуг для фортепіано» А.Рейха (1805). Про його особу у вітчизняному музикознавстві стало відомо лише з наших статей. Висновки. Тональне мислення в поліфонічному циклі Антоніна-Джозефа Рейха спрямоване в далеке майбутнє. Тональний план фортепіанного поліфонічного циклу А.Рейха «36 фуг для фортепіано» унікальний, і прецедент його відсутній. Він нібито поєднує барочне минуле й сучасне майбутнє. Поліфонічний цикл Рейха виявився своєрідною проміжною ланкою між поліфоністами епохи бароко й композиторами наступних століть, тому що ввібрав основи мислення бароко, класицизму, романтизму й багато в чому передбачив майбутнє музичної мови XX століття. Цикл має дуже складне співвідношення тональних опор першого ступеня спорідненості та їх взаємодії. Окреслюються перспективи впливу цього фортепіанного поліфонічного циклу на аналогічні жанри українських композиторів.

Ключові слова: Поліфонічний цикл А.Рейха; тональний план; перша ступінь споріднення; взаємодія тональностей; тональні опори.

Мирошниченко Светлана Владимировна, кандидат искусствоведения, профессор, профессор кафедры теории музыки и композиции Одесской национальной музыкальной академии имени А.В. Неждановой

Особенности тонального плана полифонического цикла « 36 фуг для фортепиано» Антонина Рейха

Цель статьи - рассмотреть и проанализировать взаимодействие тональностей в трех томах фортепианного полифонического цикла Антонина-Джозефра Рейха (1770-1836) «36 фуг для фортепиано» (1805) и сделать выводы о своеобразии его уникального тонального плана, а также показать перспективность проекции данного цикла для произведений последующих композиторов именно этого жанра. Методология статьи - применены методы историко-культурологического, теоретического и жанрово-стилевого анализа, что позволило осветить своеобразие и неповторимость тонального полифонического мышления, творческую индивидуальность Антонина-Джозефа Рейха в контексте дальнейшего исследования развития полифонического творчества композиторов XX века. Научная новизна заключается в том, что впервые раскрывается полифоническая творческая система Рейха, наполненная принципиальной новизной, происходящей из классического и романтического стиля композитора. Исходя из анализа фортепианного полифонического цикла «36 фуг», можно утверждать, что Рейха предвосхищает полифоническое мышление многих последующих композиторов. Творческий стиль композитора не исследовался в современном музыковедении. Впервые анализируется тональный план трех томного фоортепианного полифонического цикла эпохи классицизма А.Рейха «36 фуг для фортепиано» (1805). Да и о его личности в отечественном музыкознании стало известно только из наших статей (находятся в печати). Выводы. Тональное мышление в полифоническом цикле Антонина-Джозефа Рейха смотрит далеко в будущее. Тональный план фортепианного полифонического цикла А.Рейха «36 фуг для фортепиано» уникальный и прецедент его отсутствует. Он как бы совмещает барочное прошлое и современное будущее. Полифонический цикл Рейха

(C) Miroshnichenko S., 2019 
оказался как бі промежуточным звеном между полифонистами эпохи барокко и последующих столетий, потому что вобрав основы мышления барокко, классицизма, романтизма и во многом предвосхитил будущее музыкального языка XX столетия. Создается сложнейшее соотношение тональных опор первой степени родства и их взаимодействия. Предлагаются перспективы влияния данного фортепианного полифонического цикла на аналогичные жанры украинских композиторов.

Ключевые слова: Полифонический цикл А.Рейха; тональный план; первая степень родства; взаимодействие тональностей; тональные опоры; Й.С.Бах; Д.Шостакович; Р.Щедрин; В.Задерацкий.

Relevance of the research. Is revival of unknown or forgotten composers, works, defining some important features of their time relevant nowadays? Sometimes in the history of music amazing events happen: whole chains of constituent elements disappear from the system of historical development. This happened with Antonin-Josef Reich, a contemporary and a friend of Beethoven - a composer, theoretician, teacher, professor, who taught many great composers, an author of considerable theoretical works, on which several generations of students were taught. Having familiarized ourselves with his life and works, we began the process of revival of the personality of Antonin-Josef Reich and, as possible, his works.

An analysis of the latest publications. Antonin Reicha is almost unknown in our country. Little is known about his life and works: these are the articles in encyclopedias [4, 2, 3] and the only small Russian essay on Reicha in the monograph of I. Belza "Essays on the Development of the Czech Music Classics" without any analysis of his works [1], as well as minor foreign literature [6], encyclopedias, an introductory article to a polyphonic cycle of 36 fugues [5].

Having started with the most important for us phenomenon - the composer's polyphonic thinking that is new for the era of the Classicism, we got acquainted with his polyphonic piano cycle " 36 fugues". This turned out to be a fount of novelty, a revolutionary approach to new polyphonic thinking, style, and the formation of the genre of a "new fugue."

The tonal plan of a non-standardized polyphonic cycle consisting of 36 fugues, which are not interconnected by unusual tonal "chains," is of particular importance. The tonal plan of three volumes of the polyphonic cycle of Antonin-Josef Reicha is not a derivative of the "Well-Tempered Clavier" by J. S. Bach, is not close to the cycles of P. Hindemith, D. Shostakovich, R. Shchedrin, and polyphonic cycles of Ukrainian composers. At the same time, much of the polyphonic language of Reicha anticipates the features of the subsequent content of the polyphonic thinking of the composers of the XX century. But the tonal plan of the cycle "36 fugues" by Antonin-Josef Reicha is unique, special, and it is necessary to study it, as it was the way to the future, a bridge between the past - the Baroque and the future - the XX century.

The purpose of the article is to consider and analyze an interaction of tonalities in three volumes of $e$ piano polyphonic cycle (1770-1836) "36 fugues for piano" (1805) of Antonin-Josef Reicha and make conclusions about the peculiarity of his unique tonal plan, and also to show the perspective of the projection of this cycle for works of the subsequent composers of this genre.

Statement of the main material. As it is known, Johann Sebastian Bach (1685 - 1750) in his "Das wohltemperiert Klavier" ("Well-Tempered Clavier") asserted the chromatic even temperament of all 24 keys in both the first and second volumes of preludes and fugues (the first volume was composed in 1720-1723, the second volume in 1744).

And now we have an opportunity to restore historical justice and say that Vsevolod Petrovich Zaderatsky (1891 - 1953) in 1937 - 1939 creates "24 preludes and fugues", built on the principle of the appearance of tonalities of the circle of fourths and fifths with their parallel minor: $\mathrm{Ca}, \mathrm{Ge}, \mathrm{Dh}, \ldots \mathrm{Es}-\mathrm{C}, \mathrm{Bg}, \mathrm{Fd}$. It is significant that it was Zaderatsky who first began to create polyphonic cycles with such a tonal correlation of majors and minors.

We will not focus now on the fact that this cycle was fully released only at the beginning of the XXI century (although some preludes and fugues were known before, and selected diptychs appeared in 1983 after the publication of "Selected preludes and fugues" by V. P. Zaderatsky in the publishing house "Musical Ukraine").

Only later (in five or three years) a polyphonic cycle "Ludus tonalis" ("Tonal Game") by Paul Hindemith, was created in 1942: a prelude ... postlude, and between 12 fugues of interludes. His tonal plan is created by the composer's tonal system: falling acoustic kinship of the keys to the main: in C - in G - in F - in A in $\mathrm{E}$ - in Es - in As - in D - in B - in Des - in H - in Fis. So, there are already 12 fugues here.

Dmitry Shostakovich composes his polyphonic cycle "24 preludes and fugues", op. 87 to the 200th anniversary of the death of J. S. Bach. The cycle was created in 1950-1951, using the tonal plan of the cycle by V. P. Zaderatsky (C-a, G-e, D-h, ... Es-c, B-g, F-d).

Rodion Shchedrin does the same in his cycle "24 preludes and fugues", representing the same sequence of tonalities (the first notebook - in 1963-1964, the second one - 1964 - 1970).

A well-known Ukrainian composer V. Bibik finished his three-part cycle "34 preludes and fugues" ("Meditation," "Stress," "Enlightenment") in 1975. He created a tonally indefinite cycle, although he announced that the first volume is connected with tonalities of white keys (14 microcycles), the second - with sharp black keys (10 microcycles), the third - with flat black keys (also 10 microcycles). Keeping the general orientation of his statement, Bibik does not follow the sequence of declared keys within the volumes and uses modern tendencies of tonality-atonality (for this topic see my articles on the composer's polyphonic work). 
We shall also mention a talented work "12 concert preludes and fugues" for piano (1983) by A. Yakovchuk with the tonal plan: in $A$, in $B$, in $C$, in $D$, in $E$, in $F$, in $G$, in $A$, in $H$; in $C$ is, in $E s$, in Fis, in Gis, in $B$; using his own modal system.

We will not dwell on all the Ukrainian cycles. We will talk about them in the process of analysis of the polyphonic cycle of Antonin-Josef Reicha. Its first publication was completed in 1805.

Let us now turn to Antonin-Josef Reicha (1770 - 1836) - the brightest representative of the late Classicism - early Romanticism, a great polyphonist - theorist, teacher, composer.

As to the tonal plan of the polyphonic piano cycle "36 fugues" by Antonin Reicha. Since he is very original, individual and peculiar, we shall consider the tonal plan in detail, focusing on the correlation of tonalities of the first degree of kinship, on the tonal support and their interaction in the development of the cycle.

So, in cycle 3 of the volume with a non-standard arrangement of fugues in each and no less unusual tonal plan: V.1 - 13 fugues (№1-13); V.2 - 11 fugues (№ 14-24); V.3 - 12 fugues (№25-36).

In the first volume with 13 numbers of fugues, the tonal plan is as follows:

\begin{tabular}{|l|l|l|l|l|l|l|l|l|l|l|l|l|}
\hline 1 & 2 & 3 & 4 & 5 & 6 & 7 & 8 & 9 & 10 & 11 & 12 & 13 \\
\hline $\mathrm{A}$ & $\mathrm{G}$ & $\mathrm{f}-\mathrm{moll}$ & $\mathrm{E}$ & $\mathrm{G}$ & $\mathrm{Es}$ & $\mathrm{D}$ & $\mathrm{D}$ & $\mathrm{g}$-moll & d-moll & f-moll & $\mathrm{A} / \mathrm{G}$ & $\mathrm{C}$ \\
\hline
\end{tabular}

If not to take the repetition of the keys into account, the major ones form the sequence A-G-E-Es-D$\mathrm{C}$, and the minor ones $\mathrm{f}-\mathrm{g}-\mathrm{d}$.

Here, F12 is a tonal synthesis of F1 and F2, as if completing the first volume, forming the most important arch of the first volume. An important organizing role is played by G-dur tonality: F2, F5, and F12 also tends to it. The f-moll tonality is repeated twice: in F3 and F11, i.e. it turns out after $F 1(A)$ and $F 2(G)$, and before F12 (A / G). D-dur also appears twice in the central F7 and F8, creating a middle tonal support. The last fugue is perceived as a transition to the second and third volumes.

Let's notice that the major tonalities (9 of 12 fugues) dominate: $A-G$ - .. - E - G - Es - D - D - ... - .. ... - A / G - C. As we can see, all tonalities are sharp, only in the center of the volume there is flat Es.

A middle fugue F6 - Es-dur - is, as if, centrifugal for the minor fugues of the cycle: F3-f, F10-g, F11-f. At the same time, the minor F10 is d-moll, like C-dur, it is most likely a herald of the tonal sphere of the fugues of the second and third volumes.

The most complex tonal bonds are formed between the fugues of the first volume of the cycle. Several tonalities become the tonal bases here: A-dur; G-dur; Es-dur; C-dur. It is with them that all other fugue tonalities interact, creating the most complex interactions. It should also be noted that the C-dur tonality of the last fugue of the first volume-F13 - anticipates an important tonal content of subsequent volumes, acting as a herald to the second and third volumes of the fugues of Reicha.

Let's consider the tonal plan of the first volume, based on the correlation of tonalities of the first degree of kinship.

The scheme of the tonal supports in the first volume of the polyphonic cycle Reicha is as follows:

\begin{tabular}{|c|c|c|c|c|c|c|c|c|c|c|c|c|c|}
\hline №№ & 1 & 2 & 3 & 4 & 5 & 6 & 7 & 8 & 9 & 10 & 11 & 12 & 13 \\
\hline Tonality & $\mathrm{A}$ & $\mathrm{G}$ & $\mathrm{f}$-moll & $E$ & $G$ & Es & $\mathrm{D}$ & $\mathrm{D}$ & $\mathrm{G}$ & d-moll & f-moll & $\mathrm{A} / \mathrm{G}$ & $\mathrm{C}$ \\
\hline signature $^{\text {Key }}$ & \# & \# & b & \# & \# & b & \# & \# & \# & b & b & \#/\# & $6 / 3$ \\
\hline minor & dur & dur & moll & dur & dur & dur & dur & dur & dur & moll & moll & dur & dur \\
\hline $\begin{array}{l}\text { If } \\
\text { basis is A-dur }\end{array}$ & $T$ & & & $\mathrm{D}$ & & & S & S & & & & $\mathrm{T} /$ & \\
\hline $\begin{array}{l}\text { If tonal } \\
\text { basis is G-dur }\end{array}$ & & $T$ & & & $\mathrm{~T}$ & & D & $\mathrm{D}$ & & & & $/ \mathrm{T}$ & S \\
\hline $\begin{array}{l}\text { If tonal } \\
\text { basis is Es-dur }\end{array}$ & & & II & & & $\bar{T}$ & & & III & & II & & \\
\hline basis is $\mathrm{C}$-dur & & $\mathrm{D}$ & $\mathrm{s}$ & & $\mathrm{D}$ & & & & & II & s & /D & $\mathrm{T}$ \\
\hline $\begin{array}{l}\text { If tonal } \\
\text { basis is d-moll }\end{array}$ & $\mathrm{D}$ & & & & & & & & S & $\mathrm{t}$ & & $\mathrm{D} /$ & VII \\
\hline basis is D-dur & $\mathrm{D}$ & $S$ & & & $S$ & & $\bar{T}$ & $\bar{T}$ & $S$ & & & $\mathrm{D} / \mathrm{S}$ & \\
\hline Meter & $6 / 8$ & $\mathrm{Cl}$ & C & $\mathrm{C} \mid$ & $6 / 8$ & $\mathrm{Cl}$ & C & $6 / 8$ & $6 / 8$ & $3 / 4$ & $C$ & $2 / 8$ & $4 / 4$ \\
\hline $\begin{array}{ll}\text { voices } & \text { Quantity of } \\
\end{array}$ & 3 & $3-4$ & 4 & 4 & $3-4$ & 4 & 4 & $3-4$ & 2 & 4 & 4 & 3 & 4 \\
\hline themes & & & & 2 & & & & & & 2 & & & 2 \\
\hline (of) $\quad$ Themes & & & $\begin{array}{c}\text { Hayd } \\
n\end{array}$ & & Bach & & $\begin{array}{c}\text { Mo } \\
\text { zar } \\
t\end{array}$ & & $\begin{array}{l}\text { D.Sc } \\
\text { arlatt } \\
\text { i }\end{array}$ & & & & \\
\hline Additional & $\mathrm{Ch}$ & & & & Chor & & & Cho & Coda & & & & \\
\hline
\end{tabular}




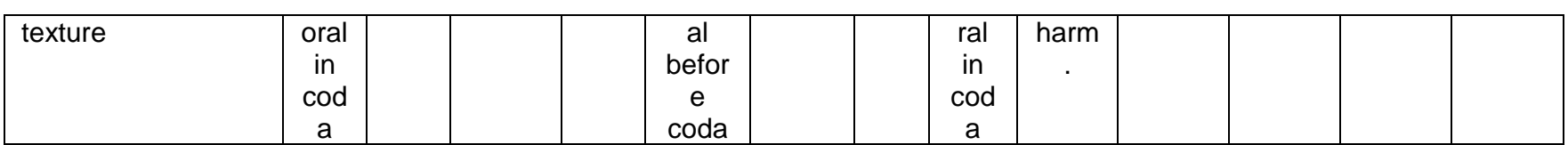

We shall remind that the themes of J. Haydn (№3), J. S. Bach (№5), V. Mozart (№7), D. Scarlatti (№9) lie at the core of the themes of not even fugues.

The tonalities of the first volume of the fugues of Reicha form the following very peculiar mode: $A$ - $G$ - (g) - $f-E$ - ... - Es - D - (d) - C. Herein the main tonal supports are A, G, C, Es (their sounds form the basis of a minor seventh chord) ... As we can see, the support tonalities of the first volume are very far apart from each other.

If to be based on A-dur tonality, then it is covered by F4, F7, F8, F12; if the tonal basis is G-dur, then it is covered by F5, F7, F8, F13 and leads to the tonality F12; basing on C-dur, are covered by F2, F3, F5, $\mathrm{F} 10, \mathrm{~F} 13$ and lead to F12; if the basis is D-dur, in which F7, F8 are created, and also runs through F1, F2, F5, tending to F12; and if the basis is Es-dur, it interacts with F2, F9, F11. Support d-moll (F10), which will continue in the second volume, is important enough.

If the tone sequence is proposed in reverse order, then C-D-d-Es-... -E-f-G-g -A is formed.

Let us now turn to the second volume of the polyphonic cycle "36 fugues for piano" (11 fugues: F1424) of Antonin Reicha and consider its tonal plan similarly to the first one. And in the future, we will dwell on its correlation with the tonal system of the first volume.

We will offer a scheme of the correlation of tonalities and tonal bases in the volume again. Fugues of the second volume are built into the main chain: $C$ - (c) - D - d - e - F - G - A - (a).

The scheme of the tonal supports of the second volume of the polyphonic cycle Reicha is as follows:

\begin{tabular}{|c|c|c|c|c|c|c|c|c|c|c|c|}
\hline №№ & 14 & 15 & 16 & 17 & 18 & 19 & 20 & 21 & 22 & 23 & 24 \\
\hline Tonality & d-moll & $\mathrm{C}$ & c-moll & a-moll & a-e & d-moll & A-F & $\mathrm{C}$ & $A-C$ & $\mathrm{D}$ & $\mathrm{G}$ \\
\hline Key signature & Flat & $\begin{array}{c}\text { no } \\
\text { key } \\
\text { sig } \\
\text { n. }\end{array}$ & b & $\begin{array}{c}\text { no } \\
\text { key } \\
\text { sign. }\end{array}$ & $-/ \#$ & b & \#D & $\begin{array}{l}\text { no } \\
\text { key } \\
\text { sig } \\
\text { n. }\end{array}$ & $\begin{array}{c}\text { no } \\
\text { key } \\
\text { sign., } \\
\#-\end{array}$ & $\begin{array}{c}\text { no } \\
\text { key } \\
\text { sign., } \\
\#\end{array}$ & \# \\
\hline Major-minor & moll & dur & moll & moll & $\begin{array}{l}\mathrm{moll} / \\
\mathrm{moll}\end{array}$ & moll & $\begin{array}{l}\text { dur/ } \\
\text { dur }\end{array}$ & dur & $\begin{array}{l}\text { dur/ } \\
\text { dur }\end{array}$ & dur & Dur \\
\hline $\begin{array}{l}\text { If tonal basis is } \\
\text { A-dur }\end{array}$ & $\mathrm{s}$ & & & & & $\mathrm{s}$ & $\mathrm{T}-$ & & $\mathrm{T}-$ & $\mathrm{S}$ & \\
\hline $\begin{array}{l}\text { If tonal basis is } \\
\text { G-dur }\end{array}$ & & $S$ & $S$ & II & II-VI & & & $S$ & $-S$ & D & $\mathrm{T}$ \\
\hline $\begin{array}{l}\text { If tonal basis is } \\
\text { Es-dur }\end{array}$ & & & VI & & & & & & & & \\
\hline $\begin{array}{l}\text { If tonal basis is } \\
\text { C-dur }\end{array}$ & II & $\mathrm{T}$ & & VI & VI-III & II & $-S$ & $\mathrm{~T}$ & $/ \mathrm{T}$ & & $\mathrm{D}$ \\
\hline $\begin{array}{l}\text { If tonal basis is } \\
\text { D-dur }\end{array}$ & & & & & /II & & $\mathrm{D} /$ & & $\mathrm{D} /$ & $\mathrm{T}$ & S \\
\hline $\begin{array}{l}\text { If tonal basis is } \\
\text { F-dur }\end{array}$ & $\mathrm{VI}$ & D & & III & III- & VI & $-T$ & D & $-\mathrm{D}$ & & \\
\hline $\begin{array}{l}\text { If tonal basis is } d- \\
\text { moll }\end{array}$ & $\mathrm{t}$ & VII & & $\mathrm{t}$ & d- & $\mathrm{t}$ & D-III & VII & D-VII & & \\
\hline Meter & $\mathrm{C} \mid$ & $\mathrm{Cl}$ & $6 / 8$ & $\mathrm{C} \mid$ & $\mathrm{C} \mid$ & $\mathrm{C}$ & $5 / 8$ & $\mathrm{C}$ & $\mathrm{C}$ & $\mathrm{C}$ & $\begin{array}{l}\text { Clot } 3 / 4 ; \\
4 / 4-3 / 4\end{array}$ \\
\hline $\begin{array}{l}\text { Quantity of } \\
\text { voices }\end{array}$ & $\begin{array}{l}\text { Choral } \\
\text { polypho } \\
\text { n. }\end{array}$ & $4(5)$ & 4 & 4 & 4 & 4 & 4 & 4 & 4 & 4 & \\
\hline Themes (of) & $\begin{array}{l}\text { Frescob } \\
\quad \text { aldi }\end{array}$ & $\begin{array}{l}\mathrm{He} \\
\text { nde } \\
\mathrm{I}\end{array}$ & & & & & & & & & \\
\hline $\begin{array}{l}\text { Quantity of } \\
\text { themes }\end{array}$ & 3 & 6 & & & 2 & & & & & & \\
\hline
\end{tabular}

Here the themes of J. Frescobaldi (No. 14), J. Hendel (No. 15) were used. Further on, the thematic material is composer's personal.

A complex tonal kinship with several supports is disclosed. The main tonalities again are G-dur, leading to the completion of the volume - F24; A-dur, the basis of F20, F22; C-dur. The tonal basis of the first volume of the polyphonic cycle Es-dur is connected with the second one only by F16 (c-moll), transferring the entire load to the third volume. As expected, the tonality of the last fugue of the first volume - C-dur - became one of the main tonal supports of the second volume, dominating in F15, F21, tending to completion in F22. Considering the tonality D-dur, which was in the central fugues of the first volume, in F7 and F8, acti- 
vated by the end of the second volume led to the penultimate F23. D-moll also becomes important - F14 (starts the second volume), F19.

Additionally in the second volume the flat tonal bases were also added: F-dur, which is absent in the first volume: F20 tends to it; there are many fugues of the second and third volumes that are in a different correlation with it. C-moll, a-moll, e-moll are also new.

In the second volume there is a movement from prevailing minor to majors (F20-24); from flat tonalities to sharp ones; as well as 5 of 11 fugues - without signs with the key in F15, F17, F21-23 (in the first volume it was only the final F13), and in C-dur fugues this is natural (F13, F15, F21), as well as for a-moll F17. The remaining fugues without a key signature refer to prominent basic tonalities. Let us recall the fugues of the XX century - R. Shchedrin, V.Bibik and others, where a key signature is often absent.

\section{F, G, A.}

Thus, the tonal supports in two volumes (first and second) are arranged in a certain order: C, d, Es,

Now we shall move to the analysis of the tonal content of 12 fugues of the third volume of the polyphonic cycle " 36 fugues" of Reicha, and then compare it with the preceding volumes.

The scheme of the tonal supports of the third volume of the polyphonic cycle of Reicha is as follows:

\begin{tabular}{|c|c|c|c|c|c|c|c|c|c|c|c|c|}
\hline Fugue № & 25 & 26 & 27 & 28 & 29 & 30 & 31 & 32 & 33 & 34 & 35 & 36 \\
\hline Tonality & A-As & C-As & $d-C$ & $A$ & $\mathrm{D}$ & $\mathrm{D}$ & E-As & Es-es & $G$ & ?-Es & G-C & $\mathrm{C}$ \\
\hline Key signature & $\begin{array}{c}\text { no } \\
\text { k.s., } \\
\text { \#-b }\end{array}$ & $\begin{array}{c}\text { no } \\
\text { k.s., } \\
b\end{array}$ & $\begin{array}{l}\text { no } \\
\text { k.s., } \\
\text { b. }\end{array}$ & $\#$ & $\begin{array}{c}\text { no } \\
\text { k.s., } \\
b\end{array}$ & $\begin{array}{c}\text { no } \\
\text { k.s., } \\
b\end{array}$ & $\begin{array}{c}\text { no } \\
\text { k.s., } \\
\text { \#-b }\end{array}$ & b & $\begin{array}{c}\text { no } \\
\text { k.s., \# }\end{array}$ & $\begin{array}{c}\text { no } \\
\text { k.s., } \\
b\end{array}$ & $\begin{array}{c}\text { no } \\
\text { k.s., } \\
\text { \#- }\end{array}$ & $\begin{array}{l}\text { No } \\
\text { k.s., }\end{array}$ \\
\hline Major-minor & M-M & M-M & $\mathrm{m}-\mathrm{M}$ & M & мин & $\mathrm{M}$ & M-M & M-M & M & $-\mathrm{M}$ & M-M & M \\
\hline $\begin{array}{l}\text { If tonal basis is } \\
\text { A-dur }\end{array}$ & T- & & s- & $T$ & $\mathrm{~S}$ & $S$ & D- & & & & & \\
\hline $\begin{array}{l}\text { If tonal basis is } \\
\text { G-dur }\end{array}$ & & S- & & & & & & & $T$ & & T-S & $\mathrm{S}$ \\
\hline $\begin{array}{l}\text { If tonal basis is } \\
\text { Es-dur }\end{array}$ & $-S$ & $-S$ & & & & & $-S$ & $T-$ & & $-T$ & & \\
\hline $\begin{array}{l}\text { If tonal basis is } \\
\text { C-dur }\end{array}$ & & $T-$ & III-T & & II & II & & & $\mathrm{D}$ & & D-T & $T$ \\
\hline $\begin{array}{l}\text { If tonal basis is } \\
\text { F-dur }\end{array}$ & & D- & VI-D & & VI & VI & & & & & $-D$ & $\mathrm{D}$ \\
\hline $\begin{array}{l}\text { If tonal basis is } \\
\text { d-moll }\end{array}$ & $S$ & VIII-- & $t-\mathrm{VII}$ & $\mathrm{D}$ & $T$ & $T$ & & & & & - VIIn & VIIn \\
\hline Meter & $\mathrm{C} \mid$ & $\mathrm{Cl}$ & $\mathrm{C}$ & $\begin{array}{l}6 / 8- \\
2 / 8 \\
6+2\end{array}$ & $C$ & $\overline{C l}$ & $\overline{C l}$ & $\mathrm{C} \mid$ & $3 / 4$ & $\mathrm{C}$ & $6 / 8$ & $C$ \\
\hline $\begin{array}{l}\text { Quantity of } \\
\text { voices }\end{array}$ & 4 & 4 & $\begin{array}{l}\begin{array}{l}3-4, \\
\text { chord }\end{array}\end{array}$ & $\begin{array}{c}3-4, \\
\text { chord } \\
\text { choral }\end{array}$ & $\begin{array}{c}\text { 4,qua } \\
\text { si } \\
\text { caden } \\
\text { ce,co } \\
\text { da- } \\
\text { choral }\end{array}$ & $3-4$ & 4 & 3 & 4 & 4 & 4 & 3 \\
\hline $\begin{array}{l}\text { Quantity of } \\
\text { themes }\end{array}$ & & & & 2 & & 3 & 2 & 2 & & 2 & & \\
\hline
\end{tabular}

Without a key signature in the third volume, there were 10 fugues out of 12 , and, what is more, this time in really different tonalities (which is justified by the chromatic system of Antonin Reicha's thinking). Finally, the major orientation of the cycle with the active use of flat tonalities is confirmed, while tending to them (in F25, F26, F31, F34).

Let's turn to the main tonality of the first volume of the cycle - A-dur (it is where F1 and 28 sound in whole), which plays a significant role again and in the third volume of the cycle: almost dominating in its initial section (F25, F29-30). We shall note the importance of A-dur as a tonality, from which the modulation (transition) to other distant tonalities begins: F20 (A-F), F22 (A-C), F25 (A-As).

The attitude towards support for G-dur tonality is also quite interesting. It is activated by the end of the whole cycle: it contains F2, F5, F24, and in the third volume of F33; F12 also leads to it, and F35 begins.

The support on d-moll is of great importance in the cycle: it runs almost through the entire third volume, leading to two fugues in this tonality within the volume - F29 and 30; also starting F27.

An explicit connection in the cycle with support on F-dur (F26, F27, F29, F30, F35, F36) continues, although there is not a single fugue created in this tonality (only in the second one, where it tends to F20). And again, Es-dur is used quite actively: it appeared in F6 of the first volume, starts F32 and completes F34.

E-dur tonality, in which only one fugue is written in the first volume of the cycle (F4), will now lead to F31, creating a certain tonal arch. 
As-dur tonality appeared, acquiring an important load in the third volume: F25, F26, F31 (with the tonal movement for a small second, for a large third, for a tritone) tend to it.

Es-moll tonality falls out of the whole previous system of tonal supports. It does not fit in tonalities of the first degree of kinship to all the supports of the cycle but is of the same name to major Es-dur (F32 is directed to it, F34 tends to it).

Let's pay attention that in the center of the first volume there were two fugues in tonality D-dur (F7, F8), in the third one this function is performed by the same tonality d-moll (F29, F30).

At the same time, a special, important value in the cycle is acquired by the tonal support and tonality, which completes the first volume of the cycle - C-dur (F13), which was dramatically activated in the second volume (F15, F21 and completes F22), and in the last volume: the cycle - №36 is completed in it; fugues No. 27 and 35 tend to this tonality; fugue № 26 deviates from it.

Conclusions. Thus, a whole system of some tonal supports, which are combined, interact with each other, run through the entire polyphonic cycle of Reicha. And these supports are of importance A, G, d, C, $\mathrm{Es}, \mathrm{F}$. If they are arranged in the order from the last key of the first (F13) and the third volumes (F36), then the following series is formed: C, d, Es, F, G, A, i.e., tonality of the first degree of kinship with the III low major and the VI major (in combination of the major-minor system).

We shall note that if earlier the variable tonality (the beginning in one key, the termination in the other) was not often used: in the first volume only in one fugue there is a transition and if the synthesis of $A$ / $G$ in F12; then in the second volume there are already two of them: F20, A / F, and F22 A / C; and in the third tonally variable fugues already literally go through the volume: F25, A / As; F26, C / As; F31, d-C; F32, E-As; F35, G-C.

Tonal thinking in the polyphonic cycle of Antonin-Josef Reicha looks far ahead into the future. The tonal of the piano polyphonic cycle " 36 fugues for piano" of A. Reicha is unique, and there is no precedent for it. It as if it combines the past of the Baroque and the modern future. The polyphonic cycle of Reicha turned out to be as if an intermediate link between polyphonists of the Baroque and subsequent centuries, because, having absorbed the basics of the thinking of the Baroque, Classicism, Romanticism, he anticipated the future of the musical language of the XX century to a great extent. A complex correlation of the tonal supports of the first degree of kinship and their interaction is created. The prospects for the influence of this polyphonic piano cycle on similar genres of Ukrainian composers are proposed.

\section{תimepamypa}

1. Бэлза И. Очерки развития чешской музыкальной классики. Москва-Ленинград: Государственное музыкальное издательство, 1951. С. 104-106. 1969. C. 178

2. Краткий биографический словарь зарубежных композиторов / сост. М. Ю. Миркин. Москва: Советский композитор,

3. Рейха (Reicha) Антон / Г. Риман. Музыкальный словарь / пер. с 5-го нем. изд., доп. русс. отд. Москва-Лейпциг: Юргенсон, 1896. С. 1097-1098.

4. Соловьева Т. Н. Рейха / Музыкальная энциклопедия / гл. ред. Ю. В. Келдыш. Москва: Советская энциклопедия, 1978. T. 4. C. $591-592$.

5. Vaclav Jan Sykora. Antonin Rejcha. 36 Fugen fur Klavier. London, 1973. P. 3-5.

6. Stephan Kunze (Munchen). Anton Reichas «Entwurf einer phrasirten Fuge» Zum Kompositionsbegriff irn fruhen 19. Jahrhunndert / Arhiv fur Musik Wissenschaft Wiesbaden, 1968. P. 280-307.

\section{References}

1. Belza I. (1951). Essays on development of Czech musical classics. Moscow-Leningrad: Gosudarstvennoe muzyikalnoe izdatelstvo [in Russian].

2. Brief biographical dictionary of foreign composers (1969). M.Yu.Mirkin (Eds.) Moscow: Sovetskiy kompozitor [in Russian].

3. Reyha (Reicha) Anton / G. Riman. Musical dictionary (1896) / per. s 5-go nem. izd., dop. russ. otd. Moscow-Leyptsig: Yurgenson [in Russian].

4. Solovieva T.N. (1978). Reicha / Musical encyclopedia (Vol. 4). Moscow: Sovetskaya entsiklopediya [in Russian].

5. Vaclav Jan Sykora (1973). Antonin Rejcha. 36 Fugen fur Klavier. London [in German].

6. Stephan Kunze (Munchen) (1968). Anton Reichas «Entwurf einer phrasirten Fuge» Zum Kompositionsbegriff irn fruhen 19. Jahrhunndert / Arhiv fur Musik Wissenschaft Wiesbaden [in German]. 